\title{
STUDIES ON PASSIVATION OF AISI 304 STAINLESS STEEL IN 0.4N/0.5N H2SO4 AND EFFECT OF OXIDIZER (MNO4-)
} ADDITION

\author{
N.N. Khobragade ${ }^{1} \&$ Dr. A.P.Patil ${ }^{2}$
}

Abstract- Austenitic stainless steel, particularly SS 304 is a popular material for application in chemical and fertilizer industry. It has excellent corrosion resistance in sulfuric acid owing to formation of a fine and compact $\mathrm{Cr}_{2} \mathrm{O}_{3}$ film. $\mathrm{Sulfuric}$ acid is an oxidizing acid but when its concentration is low, the film is not stable and does not heal by itself quickly, if damaged. Therefore, if film is damaged by turbulences or erosion, the alloy suffers from accelerated corrosion. The situation can be salvaged by addition of an oxidizer. Present study is aimed at finding out how the passivity in dilute acidic solution can be restored so that the SS 304 does not suffer from accelerated corrosion. Test solutions were $0.4 \mathrm{~N}$ and $0.5 \mathrm{~N}_{2} \mathrm{SO}_{4}$ without or with an oxidizer $\left(0.1,0.2,0.5,1\right.$ and $\left.2 \% \mathrm{KMnO}_{4}\right)$. Test method was potentiodynamic polarization with scan range of $\pm 1 \mathrm{~V}$ from open circuit potential. It is found that in absence of oxidizer the cathodic part shows instability and few segments of cathodic/anodic switch over; indicating thereby that active and passive states are stable simultaneously. This means that the passivity is not truly stable and there is risk of accelerated corrosion in case of damage to the film. On addition of oxidizer, the $\mathbf{E}_{\text {corr }}$ shifts in noble direction and the feature of simultaneous presence of active and passive state is removed. It is found that the cathodic plot has linear region extending more than two order of magnitude of current; this part is used to workout cathodic current density at OCP $\left(i_{\text {corr }}\right)$. Anodic part of the plots containing $0.1 \mathrm{KMnO}_{4}$ has no passive phase and the $i_{\text {corr }}$ obtained from cathodic part is highest. On increasing $\mathrm{KMnO}_{4}$ addition further, few plots exhibit two segment; first limiting current region and second typical passivation region. However, the current density in this region is too high for this to term as true passivity. The current density in limiting current region is also higher than $i_{\text {corr }}$ obtained from cathodic part. Thus, corrosion of stainless steel in these test solutions is under cathodic control. The optimum amount of $\mathrm{KMnO}_{4}$ both the solutions is $1 \%$. It means, on additions $1 \%$ $\mathrm{KMnO}_{4}$ to $0.4 \mathrm{~N}$ and $0.5 \mathrm{~N} \mathrm{H}_{2} \mathrm{SO}_{4}$ solutions, the passivity will become stable. However, corrosion will remain under cathodic control.

Keywords - SS 304, $\mathrm{KMnO}_{4}, \mathrm{H}_{2} \mathrm{SO}_{4}$, Corrosion

\section{INTRODUCTION}

Austenitic stainless steel, particularly SS 304 is a popular material for application in chemical and fertilizer industry. It is the most versatile and most widely used stainless steel, available in wider range of products, forms and finishes than any others. It is readily roll formed into variety of components for applications in the industrial, architectural and transformation fields [1]. It has excellent welding and forming characteristics. It has excellent corrosion resistance in a wide range of atmospheric environments and many corrosive media. It has excellent corrosion resistance in sulfuric acid owing to formation of a fine and compact $\mathrm{Cr}_{2} \mathrm{O}_{3}$ film generally called as passive film. This film acts as a reactivity barrier between the metal surface and the aggressive environment and slow corrosion reactions by many orders of magnitude and thus makes metal passive. The passivity of steel is studied by number of authors and research has been reviewed by [2] and [3].

Sulfuric acid is an oxidizing acid but when its concentration is low, the film is not stable and does not heal by itself quickly, if damaged. Moreover, the damage to the film may create a large cathode- small anode situation. Therefore, if film is damaged by turbulences or erosion, the alloy suffers from accelerated corrosion. This situation can be salvaged by addition of an oxidizer. When the metal corrodes in an acid environment, the presence of oxidizing agents like ferric, cupric, chromate ions usually increases corrosion rates. By increasing the amount of oxidizer the reversible electrode potential shifts in accordance with the Nernst equation to more noble values. In case of metals exhibiting passivity, the concentration of the oxidizer is so adjusted that the metal attains passivity and thus the corrosion rate can be controlled.

Over the years oxidizers are used to change or modify the corrosive environment to control the corrosion. These substances have a sufficiently high electrode potential and sufficiently low overpotential. Protection achieved by this method is extremely efficient. However, it has two limitations [4]. (1) This method is suitable only when concentration in the solution is sufficient to achieve passivity. If the concentration is insufficient, then it could be dangerous since critical passivation potential is not exceeded and corrosion occurs at greatly enhanced rates. And (2) Local breakdown of passivity due to oxidizer depletion could lead to pitting corrosion.

\footnotetext{
${ }_{2}^{1}$ Department of Metallurgy, Government College of Engineering, Amravati, Maharashtra, India-444 604

2 Department of Metallurgical and Materials Engineering, Visvesvaraya National Institute of Technology, Nagpur, Maharashtra, India-440 010
} 
Despite extensive studies on dissolution and passivation of SS 304 in sulphuric acid and nitric acid [5,6], only limited information is available on the use of $\mathrm{KMnO}_{4}$ as an oxidizer in dilute $\mathrm{H}_{2} \mathrm{SO}_{4}$ media and its effect on passivity of SS 304 . In this study, the effect of various concentration of $\mathrm{KMnO}_{4}$ on passivity of SS 304 in dilute $\mathrm{H}_{2} \mathrm{SO}_{4}$ media is attempted by using potentiodynamic polarization technique.

\section{EXPERIMENTAL}

The overall work is focused at finding out how passivity in dilute acidic solution can be restored so that SS 304 does not suffer from accelerated corrosion. Potentiodynamic polarization test was conducted for studying the active passive behavior of the material.

The chemical compositions of test stainless steel (type 304) is -

\begin{tabular}{|l|l|l|l|l|l|l|l|l|l|}
\hline & $\mathrm{Cr}$ & $\mathrm{Ni}$ & $\mathrm{C}$ & $\mathrm{Si}$ & $\mathrm{Mn}$ & Mo & $\mathrm{S}$ & $\mathrm{P}$ & Fe \\
\cline { 2 - 9 } \\
$\mathrm{SSS} 304$ & 18.33 & 8.32 & 0.08 & 0.45 & 1.09 & -- & 0.0042 & 0.013 & Balance \\
\hline
\end{tabular}

SS 304 was obtained in the form of sheet and then $1 \mathrm{~cm} \mathrm{X} 1 \mathrm{~cm}$ coupons were cut from it. Edges were made perfect square by grinding. The specimen were soldered to insulated copper wire and then cold mounted by using acrylic repair powder in such a way that flat surface was open and soldered joint was completely embedded. Then specimens were polished on a series of emery papers $(0 / 0,1 / 0,2 / 0,3 / 0,4 / 0$ and $5 / 0)$. It was washed with distilled water immediately and then exposed to test solution.

Test solutions (0.4 and $0.5 \mathrm{~N} \mathrm{H} 2 \mathrm{SO} 4)$ were prepared from concentrated $\mathrm{H}_{2} \mathrm{SO}_{4}$ with and without addition of $\mathrm{KMnO}_{4}(0.1 \%$, $0.2 \%, 0.5 \%, 1 \%$ and $2 \%$ by weight). To prepare $1 \mathrm{~N} \mathrm{H}_{2} \mathrm{SO}_{4}, 27.2 \mathrm{ml}$ concentrated $\mathrm{H}_{2} \mathrm{SO}_{4}$ was added to $1000 \mathrm{ml}$ of distilled water. Electrochemical cell was set-up using working electrode, reference electrode (SCE) via a luggin probe (3\%agaragar $+40 \% \mathrm{KCl}$ ) and Pt. mesh counter electrode. A gap of 2 to $3 \mathrm{~mm}$ was arranged between reference electrode and working electrode. Platinum electrode was placed such that it had clear view of working electrode. Volume of the test solution was 800 ml. Electrical connections were made with co-axial cables to Solartron 1285 potentiostat. Open circuit potential was allowed to settle at a stable value for 120 minutes. Potentiodynamic polarization test was conducted between $-1 \mathrm{~V}$ and $+1 \mathrm{~V}$ (SCE) for $\mathrm{H}_{2} \mathrm{SO}_{4}$ solutions and between $-0.5 \mathrm{~V}$ and $+1.5 \mathrm{~V}$ for $\mathrm{H}_{2} \mathrm{SO}_{4}+\mathrm{KMnO}_{4}$ solutions. Temperature of test solution was $30^{\circ} \mathrm{C}$ during the test. Polarization curve (E Vs log i) were obtained.

\section{RESULTS AND DISCUSSION}

The data derived from these plots is presented in Table 1 and Table 2 . These tests were conducted to find out electrochemical evidence of acid concentration on corrosion behavior. Tests were also conducted to find out acid the effect of oxidation $\left(\mathrm{KMnO}_{4}\right)$ addition on corrosion rate. These plots and electrochemical data give insight into passivation characteristics of SS 304 in sulphuric acid environments with or without $\mathrm{KMnO}_{4}$

Table.1: Electrochemical data derived from potentiodynamic polarization plots for SS 304 in various $\mathrm{H}_{2} \mathrm{SO}_{4}$ solutions

\begin{tabular}{|l|l|l|l|l|l|}
\hline Solutions & OCP & E pass & I pass & E b & Ib \\
\hline $0.4 \mathrm{~N} \mathrm{H2SO4}$ & -0.3832 & 0.005916 & $1.2409 \times 10^{-5}$ & 0.87874 & $4.7757 \times 10^{-5}$ \\
\hline $0.5 \mathrm{~N} \mathrm{H2SO4}$ & -0.1665 & 0.021602 & $1.3665 \times 10^{-5}$ & 0.86337 & $3.0769 \times 10^{-5}$ \\
\hline
\end{tabular}

\subsection{Passivity in $\mathrm{H}_{2} \mathrm{SO}_{4}$}

The results are presented in Table1 and Figure 1. It is evident that critical current density nose is missing; indicating thereby that SS304 quickly passivates in these solutions. There are no definite trends as to effect of $\mathrm{H}_{2} \mathrm{SO}_{4}$ concentration on passivation current. The breakdown potential $\mathrm{E}_{\mathrm{b}}$ is not much affected by concentration of $\mathrm{H}_{2} \mathrm{SO}_{4}$ solution and $\mathrm{E}_{\mathrm{b}}$ remains almost in the same range i.e. $0.85 \mathrm{~V}(\mathrm{SCE}) \pm 0.08 \mathrm{mV}$.

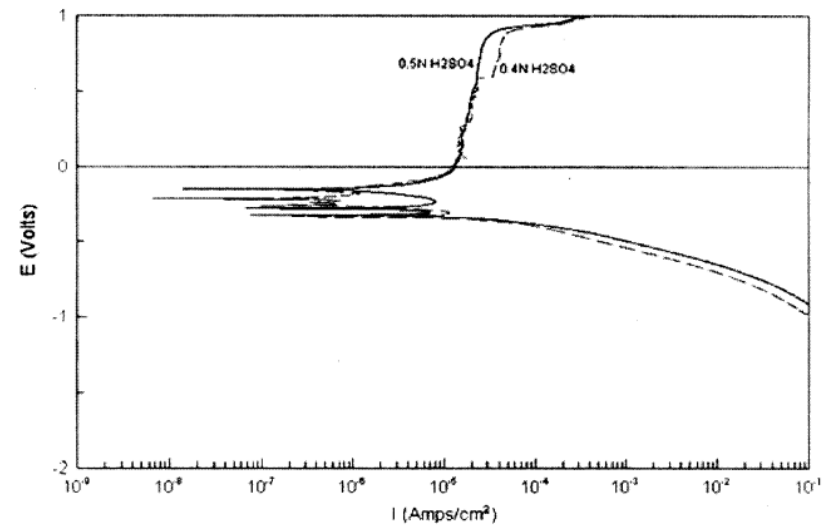

Fig.1: Potentiodynamic graph for $0.4 \mathrm{~N} \mathrm{H}_{2} \mathrm{SO}_{4}$ and $0.5 \mathrm{~N} \mathrm{H}_{2} \mathrm{SO}_{4}$ solutions 
Cathodic part however indicates instability, indicating thereby that the cathodic line intersects apparent active/passive transition in anodic part and thus current becomes positive, then negative and then positive in both the cases. There are two such changeovers. Such changeovers are not desirable because if passive film is somehow damaged then the alloy undergoes active corrosion. Although, eventually passivity will set in but damage due to active corrosion may be more than expected of an alloy with self healing film. In such cases increasing solution potential (by addition of oxidizer) may remove this feature. Therefore few tests were conducted with addition of $\mathrm{KMnO}_{4}$ to $\mathrm{H}_{2} \mathrm{SO}_{4}$ solution.

\subsection{Passivity in presence of $\mathrm{KMNO}_{4}$}

The potentiodynamic polarization plots for these conditions are presented in Figs. 2 to 5. The electrochemical data derived from these plots is presented in Table 2. It is evident from the Figs and the data that open circuit potential of SS 304 is increasing in the noble direction with increasing $\mathrm{KMnO}_{4}$ concentration. This indicates that with increasing addition of $\mathrm{KMnO}_{4}$, an oxidizer, SS 304 is becoming less prone to corrode. This indicates that SS 304 is passivating and extent of passivation is increasing with increasing $\mathrm{KMnO}_{4}$ content. Secondly, on increasing $\mathrm{KMnO}_{4}$ content $\mathrm{i}_{\text {crit }}$ is increasing, indicating thereby that the active corrosion region is increasing before a compact passive film is formed. These graphs are similar to the polarization graphs obtained by Pandey [7] and coworkers for SS 304 in $75 \% \mathrm{H}_{2} \mathrm{SO}_{4}+\mathrm{HNO}_{3}$.

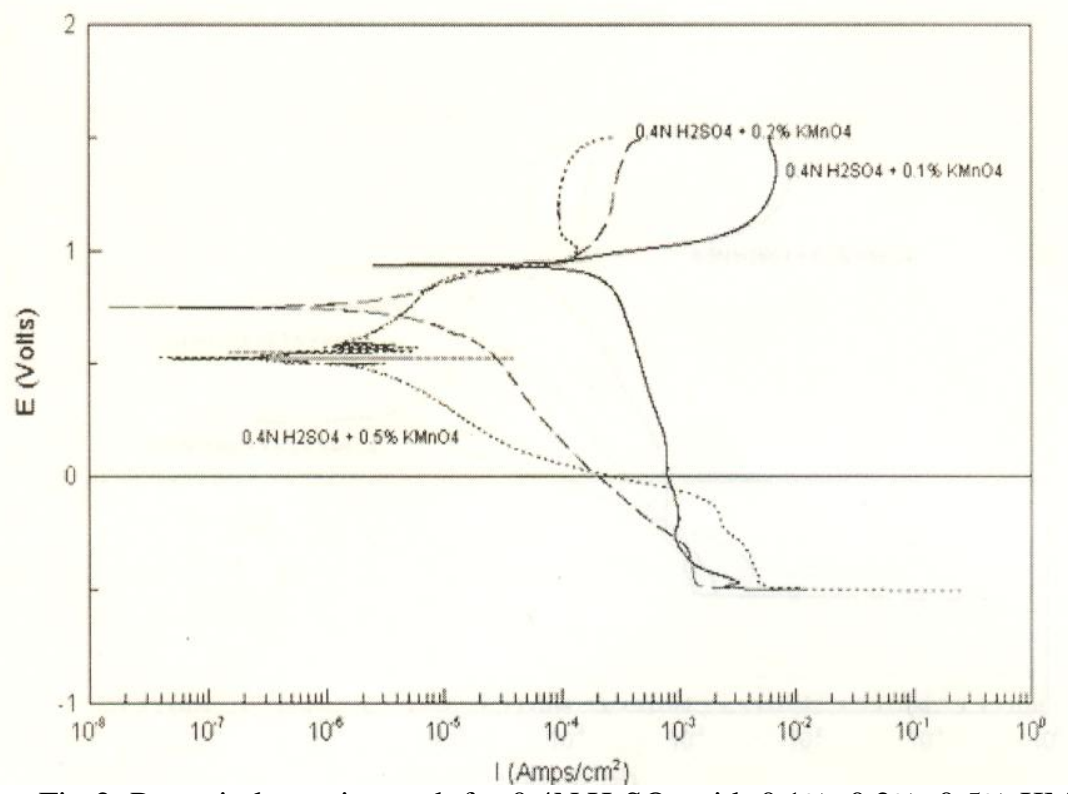

Fig.2: Potentiodynamic graph for $0.4 \mathrm{~N} \mathrm{H}_{2} \mathrm{SO}_{4}$ with $0.1 \%, 0.2 \%, 0.5 \% \mathrm{KMnO}_{4}$

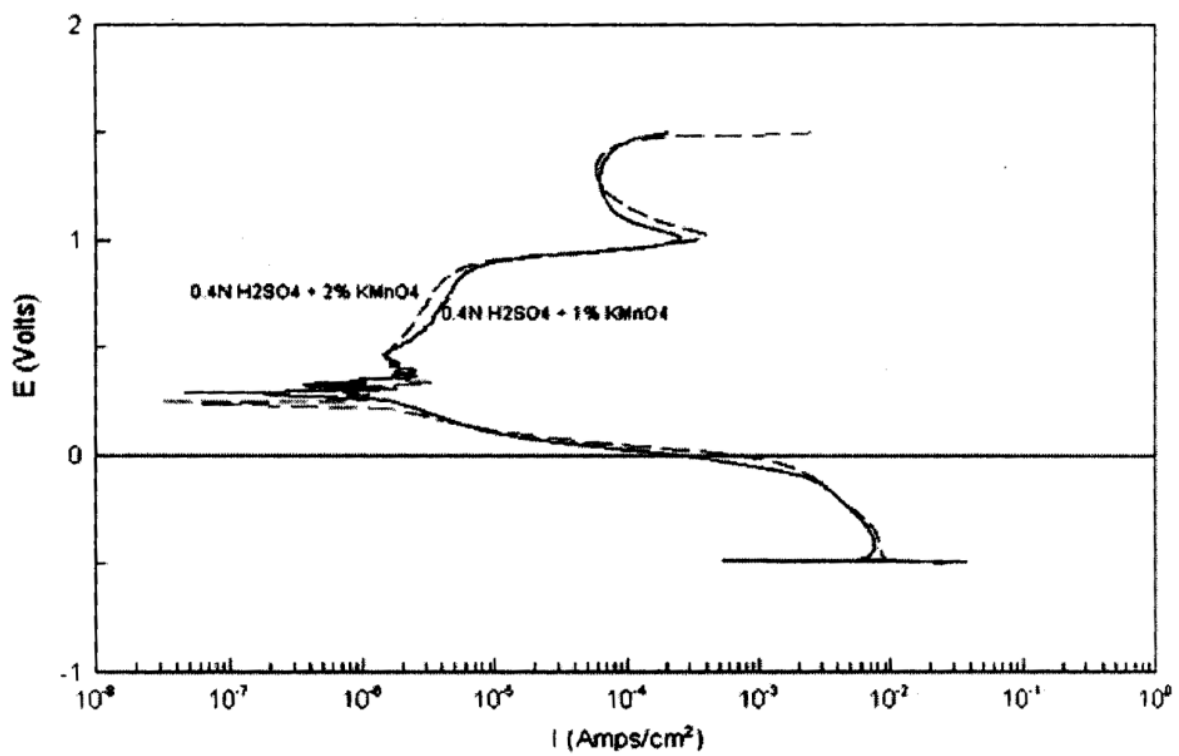

Fig.3: Potentiodynamic graph for $0.4 \mathrm{~N} \mathrm{H}_{2} \mathrm{SO}_{4}$ with $1 \%, 2 \% \mathrm{KMnO}_{4}$ 
In general, SS304 exhibits primary and secondary passivity. In some cases primary passivity is missing and instead active regions observed. Occurrences of secondary passivity in almost all cases indicate that alloy has film forming tendency and the breakdown potential of film is quite high i.e. above $0.85 \mathrm{~V}$ (SCE) and as high as $1.48 \mathrm{~V}$ (SCE). Owing to the fact that anodic current density is much higher than cathodic current density, this passivity is of no significance as far as corrosion controlling step is concerned and the corrosion remains to be under cathodic control.

At the operating potentials i.e. $\mathrm{E}_{\mathrm{corr}}$ in solution with $\mathrm{pH}=1.1$, the hydrogen evolution will start at potential lower than potential calculated from equation-

$\mathrm{E}=-0.59 \times \mathrm{pH}=-0.59 \times 1.1=0.649 \mathrm{~V}(\mathrm{SHE})=0.408 \mathrm{~V}(\mathrm{SCE})$

Table.2: Electrochemical data derived from potentiodynamic polarization plots for $\mathrm{SS} 304$ in various solutions $\left(\mathrm{HS}^{2} \mathrm{~N}_{2} \mathrm{SO}_{4}\right.$, $\mathrm{KM}=\% \mathrm{KMnO}_{4}$ )

\begin{tabular}{|c|c|c|c|c|c|c|c|c|c|c|c|}
\hline Solution & OCP & E corr & I corr & I pp & E pp & $\mathrm{Ib}$ & $\mathrm{Eb}$ & I crit & E crit & I pp2 & E pp2 \\
\hline $\begin{array}{l}0.4 \mathrm{HS}^{*}+ \\
0.1 \mathrm{KM}^{*}\end{array}$ & $\begin{array}{l}0.538 \\
1\end{array}$ & $\begin{array}{l}0.9358 \\
4\end{array}$ & $\begin{array}{l}80.293 \\
0\end{array}$ & & & & & & & & \\
\hline $\begin{array}{l}0.4 \mathrm{HS}+0 . \\
2 \mathrm{KM}\end{array}$ & $\begin{array}{l}0.791 \\
1\end{array}$ & $\begin{array}{l}0.7502 \\
7\end{array}$ & 1.5876 & $\begin{array}{l}255.230 \\
0\end{array}$ & $\begin{array}{l}1.1417 \\
0\end{array}$ & $\begin{array}{l}394.310 \\
0\end{array}$ & $\begin{array}{l}1.4697 \\
0\end{array}$ & & & & \\
\hline $\begin{array}{l}0.4 \mathrm{HS}+0 . \\
5 \mathrm{KM}\end{array}$ & $\begin{array}{l}0.915 \\
6\end{array}$ & $\begin{array}{l}0.4977 \\
4\end{array}$ & 1.6643 & & & & & $\begin{array}{l}138.830 \\
0\end{array}$ & 1.003 & 95.6720 & $\begin{array}{l}1.2016 \\
0\end{array}$ \\
\hline $\begin{array}{l}0.4 \mathrm{HS}+1 \\
\mathrm{KM}\end{array}$ & $\begin{array}{l}0.989 \\
9\end{array}$ & $\begin{array}{l}0.2782 \\
7 \\
\end{array}$ & 1.2034 & 3.0656 & $\begin{array}{l}0.6002 \\
9\end{array}$ & 5.6872 & $\begin{array}{l}0.8355 \\
2\end{array}$ & $\begin{array}{l}256.950 \\
0\end{array}$ & $\begin{array}{l}1.0058 \\
0\end{array}$ & 62.5760 & $\begin{array}{l}1.2819 \\
0\end{array}$ \\
\hline $\begin{array}{l}0.4 \mathrm{HS}+2 \\
\mathrm{KM}\end{array}$ & $\begin{array}{l}0.984 \\
3\end{array}$ & $\begin{array}{l}0.2217 \\
2\end{array}$ & 1.3521 & 2.2543 & $\begin{array}{l}0.5854 \\
2\end{array}$ & 4.8544 & $\begin{array}{l}0.8473 \\
3\end{array}$ & $\begin{array}{l}411.150 \\
0\end{array}$ & 1.0188 & 58.5040 & $\begin{array}{l}1.3248 \\
0\end{array}$ \\
\hline $\begin{array}{l}0.5 \mathrm{HS}+0 . \\
1 \mathrm{KM}\end{array}$ & $\begin{array}{l}0.564 \\
5 \\
\end{array}$ & $\begin{array}{l}0.9215 \\
8\end{array}$ & $\begin{array}{l}37.398 \\
0\end{array}$ & & & & & & & & \\
\hline $\begin{array}{l}0.5 \mathrm{HS}+0 . \\
2 \mathrm{KM}\end{array}$ & $\begin{array}{l}0.856 \\
4\end{array}$ & $\begin{array}{l}0.7310 \\
9\end{array}$ & 3.3858 & $\begin{array}{l}155.350 \\
0\end{array}$ & $\begin{array}{l}0.9918 \\
3\end{array}$ & $\begin{array}{l}130.550 \\
0\end{array}$ & $\begin{array}{l}1.0882 \\
0\end{array}$ & $\begin{array}{l}155.350 \\
0\end{array}$ & $\begin{array}{l}0.9918 \\
3\end{array}$ & $\begin{array}{l}130.550 \\
0\end{array}$ & $\begin{array}{l}1.0882 \\
0\end{array}$ \\
\hline $\begin{array}{l}0.5 \mathrm{HS}+0 . \\
5 \mathrm{KM}\end{array}$ & $\begin{array}{l}0.908 \\
6 \\
\end{array}$ & $\begin{array}{l}0.2534 \\
4 \\
\end{array}$ & 2.6887 & $\begin{array}{l}131.370 \\
0\end{array}$ & $\begin{array}{l}0.5816 \\
7 \\
\end{array}$ & 17.9700 & $\begin{array}{l}0.8544 \\
6 \\
\end{array}$ & $\begin{array}{l}110.310 \\
0\end{array}$ & $\begin{array}{l}0.9699 \\
5\end{array}$ & 48.8210 & $\begin{array}{l}1.3025 \\
0\end{array}$ \\
\hline $\begin{array}{l}0.5 \mathrm{HS}+1 \\
\mathrm{KM}\end{array}$ & $\begin{array}{l}0.958 \\
6\end{array}$ & $\begin{array}{l}0.3157 \\
0\end{array}$ & 1.5585 & $\begin{array}{l}101.250 \\
0\end{array}$ & $\begin{array}{l}0.6119 \\
7\end{array}$ & 13.1240 & $\begin{array}{l}0.8317 \\
1\end{array}$ & $\begin{array}{l}276.440 \\
0\end{array}$ & $\begin{array}{l}1.0162 \\
0\end{array}$ & 88.4630 & $\begin{array}{l}1.3530 \\
0\end{array}$ \\
\hline $\begin{array}{l}0.5 \mathrm{HS}+2 \\
\mathrm{KM}\end{array}$ & $\begin{array}{l}0.956 \\
1\end{array}$ & $\begin{array}{l}0.9222 \\
5\end{array}$ & $\begin{array}{l}10.285 \\
0\end{array}$ & & & & & $\begin{array}{l}685.980 \\
0\end{array}$ & $\begin{array}{l}1.0556 \\
0\end{array}$ & $\begin{array}{l}329.750 \\
0\end{array}$ & $\begin{array}{l}1.2683 \\
0\end{array}$ \\
\hline
\end{tabular}

*HS means $\mathrm{H}_{2} \mathrm{SO}_{4}$ and $\mathrm{KM}$ means $\mathrm{KMnO}_{4}$

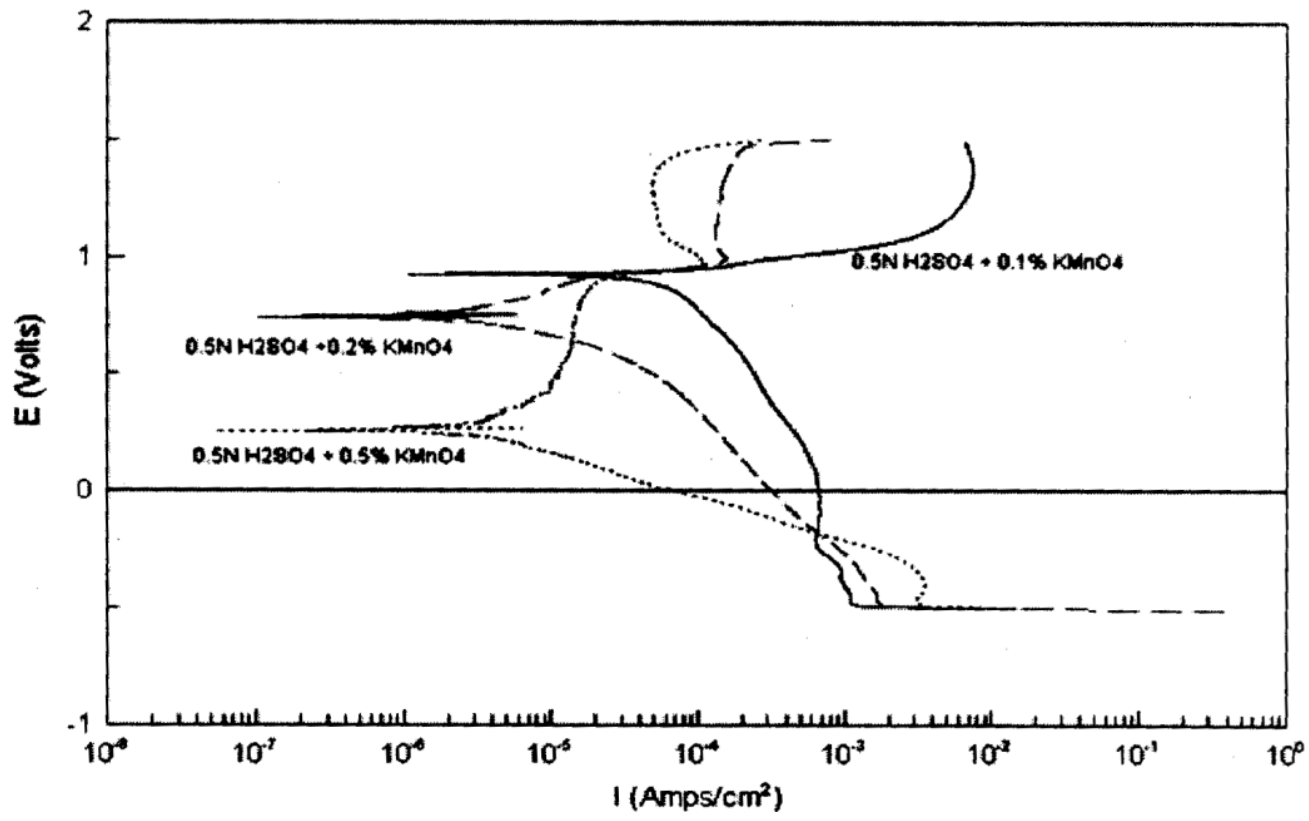

Fig.4: Potentiodynamic graph for $0.5 \mathrm{~N} \mathrm{H}_{2} \mathrm{SO}_{4}$ with $0.1 \%, 0.2 \%, 0.5 \% \mathrm{KMnO}_{4}$ 
Since the OCP/ $\mathrm{E}_{\text {corr }}$ are much higher than $0.408 \mathrm{~V}$ (SCE), there is no possibility of hydrogen reduction. This indicates that oxygen reduction may occur as a cathodic counterpart.

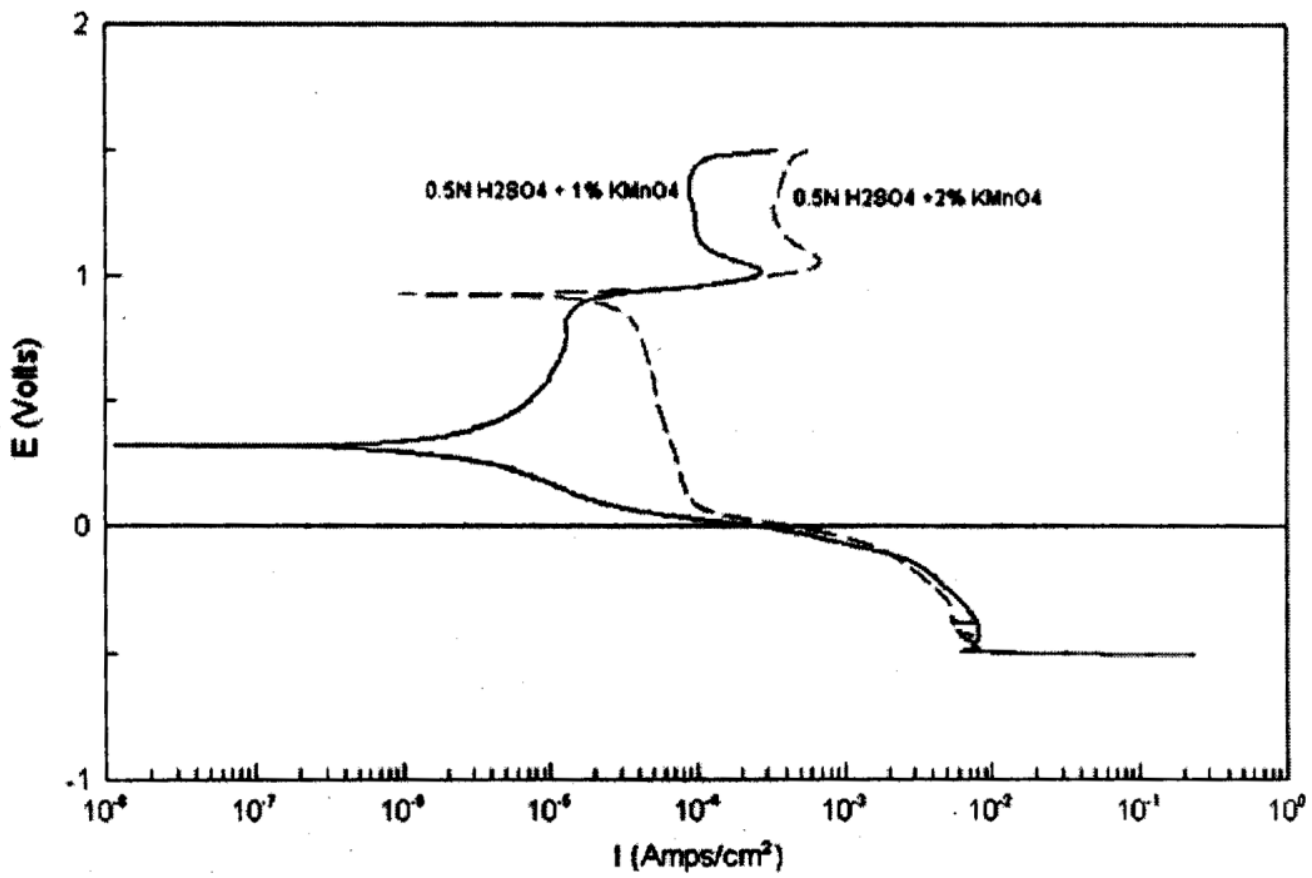

Fig.5: Potentiodynamic graph for $0.5 \mathrm{~N} \mathrm{H}_{2} \mathrm{SO}_{4}$ with $1 \%, 2 \%, \mathrm{KMnO}_{4}$

Most importantly the instability in cathodic part in case of $\mathrm{H}_{2} \mathrm{SO}_{4}$ solution is not observed in these test-solutions. This proves that addition of $\mathrm{KMnO}_{4}$ shifts solution potential to a noble value, removes instability and thus makes the film self healing. In that sense similarity of polarization plots with those obtained by Pandey and coworkers [7] for SS 304 in $75 \% \mathrm{H}_{2} \mathrm{SO}_{4}+25 \%$ $\mathrm{HNO}_{3}$, may be attributed to oxidizing nature of $\mathrm{KMnO}_{4}$.

\section{CONCLUSION}

Anodic part of the plots containing $0.1 \mathrm{KMnO}_{4}$ has no passive phase and the $\mathrm{i}_{\text {corr }}$ obtained from cathodic part is highest. On increasing $\mathrm{KMnO}_{4}$ addition further, few plots exhibit two segment; first limiting current region and second typical passivation region. However, the current density in this region is too high for this to be termed as true passivity. The current density in limiting current region is also higher than $i_{\text {corr }}$ obtained from cathodic part. Thus, corrosion of stainless steel in these test solutions is under cathodic control. The optimum amount of $\mathrm{KMnO}_{4}$ for both the solutions is $1 \%$. It means, on additions $1 \%$ $\mathrm{KMnO}_{4}$ to $0.4 \mathrm{~N}$ and $0.5 \mathrm{~N} \mathrm{H}_{2} \mathrm{SO}_{4}$ solutions, the passivity will become stable and SS 304 will remain protected.

\section{REFERENCES}

[1] A. John Sedriks, Corrosion of stainless steels, John Wiley \& sons, 1996, 13-78.

[2] Patrik Schmuki, J. Solid State Electrochem 6 (2002).

[3] C.-O.A. Olsson, D. Landolt, Electrochimica Acta 48 (2003)

[4] Raj Narayan, An Introduction to corrosion and its prevention, Oxford and IBH, 1991, 64-66.

[5] Bore Jegdic, Dragutin M. Drazic, Jovan P. Popic, J. Serb. Chem. Soc. 71(5) 2006.

[6] D.G. Kolman and coworkers, Corr. Sci., Vol. 39, No. 12, 1998

[7] (7) J.L. Pandey and coworkers, Anticorrosion methods and materials, Vol.44, 1997. 